\title{
Fishing operations to catch tuna on aggregated schools at the vicinity of a data buoy in the Western Equatorial Atlantic
}

\author{
Guelson Batista da Silva ${ }^{1}$, Humberto Gomes Hazin ${ }^{1}$, Paulo Víctor Araújo do Nascimento ${ }^{2}$
}

\author{
${ }^{1}$ Universidade Federal Rural do Semi-Árido - Departamento de Ciências Animais \\ (Av. Francisco Mota, 572 - Bairro Costa e Silva - 59.625-900 - Mossoró - RN - Brazil) \\ ${ }^{2}$ Instituto Federal de Educação, Ciência e Tecnologia do Rio Grande do Norte - Campus Macau \\ (Rua das Margaridas, 300, Conjunto COHAB - 59.500-000 - Macau - RN - Brazil) \\ *Corresponding author: guelson@ufersa.edu.br
}

The overfishing of the spiny lobster (Panulirus spp.) in Brazil caused by high fishing effort level and use of predatory illegal gears has called for new alternatives to make up for their dwindling stocks. One of those has been the development of a fishery carried out by a small wooden fleet based at Areia Branca, RN, Northeast Brazil, targeting tunas and tuna-like species in the vicinity of data buoys from the Pilot Moored Array in the Tropical Atlantic Program (PIRATA), which happen to act unintentionally as Fishing Aggregating Device (FAD) (Silva et al., 2016).

The fishing activity based on the use of PIRATA data buoys as FADs in the Western Atlantic has been poorly described previously (Silva et al., 2013). There were also similar experiences carried out in the Pacific Ocean in the neighborhood of the TAO (Tropical Atmospheric/Ocean) Program installations (Servain et al., 1998). Right at the beginning of PIRATA Program, two buoys were deactivated in the Eastern Atlantic because of unwanted fishing activities (Bourlès et al., 2008).

Even being common, there are few records on the use of data buoys as FADs in the scientific literature. Relini et al. (1994) identified a data buoy in the Mediterranean acting as FAD, and thereafter Relini et al. (2000) reported the use by artisanal fishermen of a weather buoy installed in the Mediterranean islands of Malta, Sicily and Majorca. Josse and Bertrand (2000) conducted studies to estimate the biomass and species composition associated with a buoy of the TOGA (Tropical Ocean Global Atmosphere) Program. In Hawaii, the handline fisheries are based on juveniles of bigeye and yellowfin tunas associated with offshore weather monitoring buoys (Itano and Holland,

Submitted on: 05/April/2018

Approved on: 09/December/2018

http://dx.doi.org/10.1590/S1679-87592018018206604
2000). In Australia, oceanographic monitoring buoys are also utilized by recreational fishermen (Dempster, 2004).

Thus, the present study aims to describe the fishing technology and methods to catch tunas on aggregated schools, the spatial distribution of the fishing activities in the vicinity of the data buoy, identifying and discussing the likely impacts derived from these actions.

The main buoy used in this fishery is located at the geographic position $00^{\circ} \mathrm{N}-35^{\circ} \mathrm{W}, 323$ nautical miles away from the fishing pier at Areia Branca, RN (Figure 1). The information were obtained on board during five fishing trips for Jan/2011 to Dec/2012, regarding technological features such as fleet, fishing gears and baits, complemented by interviews with crew members.

The positions of fishing operations were recorded by a Global Positioning System (GPS) device, which were used to produce thematic maps, by the ArcGIS software version 9.3, which show the spatial distribution of fishing activities.

The tuna fleet was composed by nine wooden motorboats with the following specifications: length overall (LOA) from $12.5 \mathrm{~m}$ to $14.4 \mathrm{~m}$ (mean \pm standard deviation $=13.4 \pm 0.67 \mathrm{~m}$ ); Gross Tonnage (GT) ranging from 16.9 to 33.1 (20.4 \pm 4.9 ); average power engine of 110HP; average fuel capacity of 1,320 diesel gallons; and 8 to 15 ton in the fish hold capacity. Such features have a direct bearing on their seaworthiness. They are also equipped with GPS for navigation and buoy location, color echo sounder for monitoring the fish schools, and SSB and VHF radio for long and short communication, respectively. The boats spent an average 60 -hour voyage to reach the buoy where the fishing activities are concentrated and fishing trips last generally from 15 to 25 days.

As a way of adjustment to tuna fisheries, light attractors were installed which are deemed essential for concentrating flying-fish at night, and individual insulated boxes 


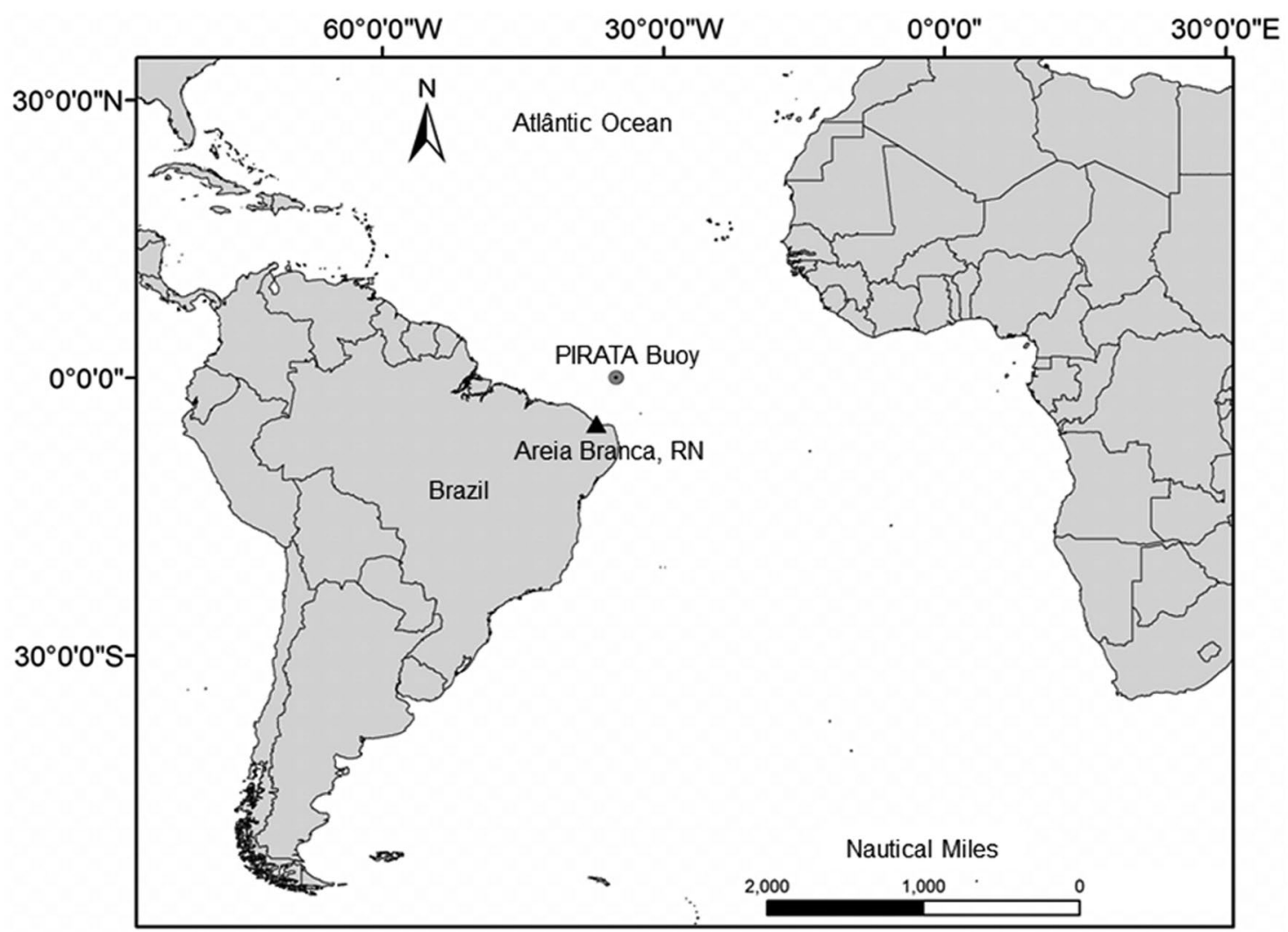

Figure 1. Map showing the location of Areia Branca city, Northeastern Brazil, and the location of PIRATA buoy in the western equatorial Atlantic.

were placed on deck so as to increase the capacity of ice storage and facilitate the fish handling on board.

Trolling is the first technique practiced in the route to the fishing ground, in the surrounding of the data buoy, or even in eventual drifting objects found by the fisherman. Some boats had adapted to the system of side stick pole and the others usually tied the trolling lines to the stern. The fishing lines are made of polyamide monofilaments at two different diameters. First one with $1.8 \mathrm{~mm} \emptyset$ equipped with silicone, plastic or fiberglass lures, targeting wahoo and common dolphinfish, and the other with $1.2 \mathrm{~mm} \varnothing$ and rubber bait cut in a fish shape targeting skipjack and juvenile bigeye and yellowfin, which can be used as live bait or stocked for sale.

The handlines are made of polyamide monofilament ranging from 1.2 to $2.5 \mathrm{~mm} \varnothing$, according to the target species. They carry J-type hooks or triple-type ones. Gaffs and harpoons work as auxiliary gear, given their usefulness for hauling the larger specimens onto the deck. Catching is performed either with the boat moving upwind at an average 2-knot speed while fishing for juvenile yellowfin and bigeye tuna or drifting while fishing for common dolphinfish with strips of fish as bait and larger specimens of yellowfin tuna with live skipjack or juvenile tunas $(<50 \mathrm{~cm} \mathrm{FL})$ as bait.

A local version of the handline named "boleado" is comprised of three sections of polyamide monofilament: the first one with $180 \mathrm{~m}$ and $1.8 \mathrm{~mm} \varnothing$, one intermediate and short section with $0.45 \mathrm{~m}$ and $3 \mathrm{~mm} \varnothing$ with one sinker that is released during the hauling if some fish is caught, and the final section with $20 \mathrm{~m}$ and $1.2 \mathrm{~mm} \varnothing$. This technique is directed to deeper zones at night targeting adult and juvenile bigeye and yellowfin tunas.

There are two kinds of bamboo poles: the short one, with $2.7 \mathrm{~m}$ in total length and $3 \mathrm{~cm}$ in diameter, equipped with polyamide monofilament $1.6 \mathrm{~mm} \emptyset$, usually attached to barbless or J-type hooks baited with raffia or silicone lure, respectively. The other one is longer, with approximately $4.5 \mathrm{~m}$ in length, whose line is divided into two sections, both made of polyamide monofilament, with $1.8 \mathrm{~mm} \varnothing$ and $1.6 \mathrm{~mm} \varnothing$, and using J-type hooks baited with silicone lure. At the tip of the pole there is a slit through which passes the line, remaining free until such time as it starts being hand-operated by the 
fisherman. These techniques are more efficient in the daytime, with the boat moving upwind at an average 2-knot speed and catching mostly juveniles of bigeye and yellowfin tunas.

Two different operational strategies were identified along the study period, where initially the efforts were concentrated on the surroundings of the data buoy, with the activities of fishing alternating between trolling and handline, particularly in the northwestern area, depending on the direction of prevailing currents and winds at the site (Figure 2).

As the main impacts of the fishery around the PIRATA data buoys, we can point out the fact that some boats are tied up in the buoy structure and some fishing materials get entangled in the mooring system, mainly from handline sinkers. From the environmental point of view, we can also mention the juveniles catches for trading or to be used as bait.

Therefore, the fleet has changed their strategy, starting to operate with the school aggregated with the own fishing boat, transferring it to another boat right after reaching the maximum capacity of storage, operation that was observed both at night and daytime. The main fishing activity is pole and line, which is developed southward of the buoy location, a factor that generates a fuel economy, since such positions are located at a shorter distance from the coast (Figure 2).

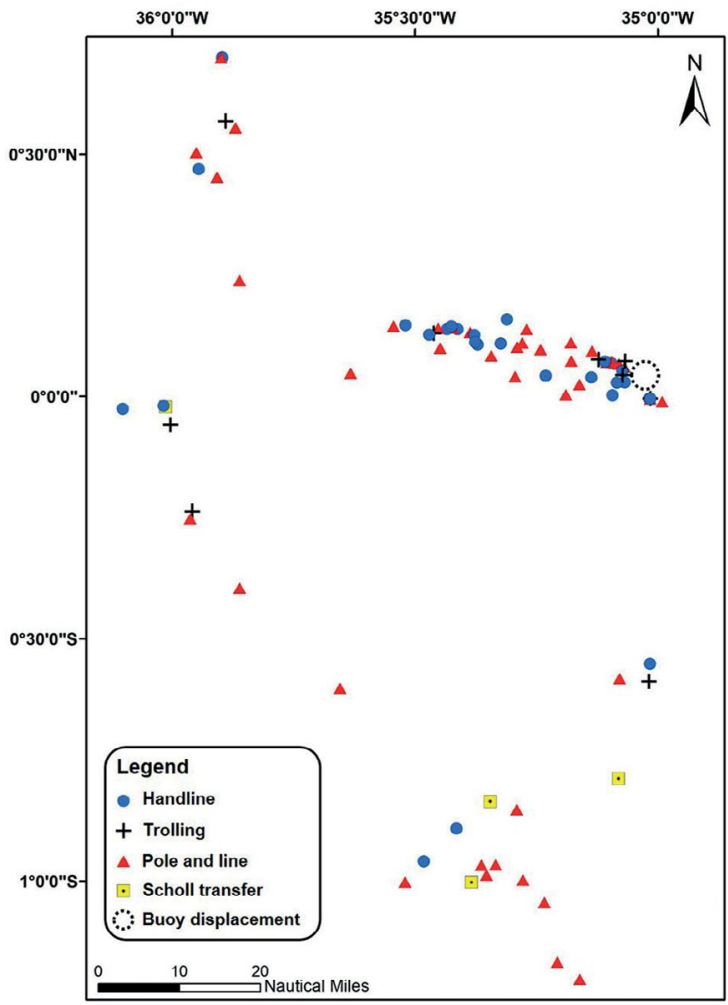

Figure 2. Spatial distributions of fishing operations in the surrounding area of PIRATA data buoy in the western equatorial Atlantic.
Artisanal fishermen are often unaware of the potential yield of fisheries close to FAD's due to the lack of feasible fishing technologies, or even by the inaccessibility to ideal fishing equipment (Preston et al., 1998). In the case of the fleet of Areia Branca, enhancements in the fishing methods raised from their own experience, as well from interactions with other fleets, which also exploit tunas on aggregated schools in the area.

Among the most important benefits from the viewpoint of the local fleet, we can underscore the reduction in fishing effort in coastal areas, creating new job opportunities, and enhancing income and revenues. As an offshoot, auxiliary industries and services have also come into play as fish trading stores, ice manufacturing, building and maintenance of fishing craft and fuel supply. Examples of the success in using FAD's to lessen fuel costs on the localization of shoals in the open sea can be found in Matsumoto et al. (1981) and Feigenbaum et al. (1989), which unfortunately are not the case with the Areia Branca fleet because of the long traveling distance to the PIRATA buoy. According to Silva et al. (2013) the fuel is one of the main variable costs in this activity.

Since there are no specific laws to prevent fishing activities around data buoys, the main efforts to prevent this kind of impact have been limited mainly to education and outreach programs conducted to raise fisherman awareness about the importance of data buoys. It is also important to highlight the recommendations by tuna Regional Fisheries Management Organizations (RFMOs) such as the Western and Central Pacific Fisheries Commission (WCPFC) and the Inter-American Tropical Tuna Commission (IATTC) which established that 1 nautical mile is the limit distance for the fishing activities around data buoys. There is also a real concernment from International Commission for the Conservation of Atlantic Tuna (ICCAT) about tuna fisheries on FADs, which lead to a creation of an Ad Hoc Working Group, but the main effort was always concentrated on the issue of drifting FADs, generally deployed at eastern Atlantic by the purse seine fleet. Alternatively, the development of a FAD program in Brazilian waters could reduce the fishing activity associated with the PIRATA Program data buoys.

Actually, there is a real expansion of the fleet mainly at Rio Grande do Norte and Ceará States, northeastern Brazil, with the building of larger fishing boats, which is leading to a natural spreading of the spatial distribution of the fishing operations, including other PIRATA buoys. Everything is happening without proper monitoring measures. Thus, we 
recommend to the Brazilian Management Officers the adoption of a license system entailed to a trip formulary, with information about production, species composition, kind of FAD and geo-localization, among others.

Therefore, is possible to establish that this tuna fishery plays an important role as an alternative to stocks overfishing in coastal areas off northeastern Brazil, in the Western equatorial Atlantic. Nevertheless, it is necessary to carry out further studies for a suitable understanding of this activity, especially regarding its impacts on exploited stocks. The development of an education and outreach program should be the most feasible way to arise the fishermen awareness about the importance on preservation of data buoys.

\section{REFERENCES}

BOURLÈS, B., LUMPKIN, R., MCPHADEN, M. J., HERNANDEZ, F., NOBRE, P., CAMPOS, E., YU, L., PLANTON, S., BUSALACCHI, A., MOURA, A. D., SERVAIN, J. \& TROTTE, J. 2008. The PIRATA Program: History, Accomplishments and Future Directions. Bulletin of the American Meteorology Society, 89, 1111-1125.

DEMPSTER, T. 2004. Biology of fish associated with moored fish aggregation devices (FADs): implications for the development of a FAD fishery in New South Wales, Australia. Fisheries Research, 68, 189-201.

FEIGENBAUM, D., FRIEDLANDER, A. \& BUSHING, M. 1989. Determination of the feasibility of fish attracting devices for enhancing fisheries in Puerto Rico. Bulletin of Marine Science, 44, 950-959.
ITANO, D. G. \& HOLAND, K. N. 2000. Movement and vulnerability of bigeye (Thunnus obesus) and yellowfin tuna (Thunnus albacares) in relation to FADs and natural aggregation points. Aquatic Living Resources, 13, 213-223.

JOSSE, E. \& BERTRAND, A. 2000. In situ acoustic target strength measurements of tuna associated with a fish aggregating device. ICES Journal of Marine Science, 57, 911-918.

MATSUMOTO, W. M., KAZAMA, T. K. \& AASTED, D. C. 1981. Anchored Fish Aggregating Devices in Hawaiian Waters. Marine Fisheries Review, 43, 1-13.

PRESTON, G. L., CHAPMAN, L. B. \& WATT, P. G. 1998. Vertical longlining and other methods of fishing around Fish Aggregating Devices (FADS). Noumea, New Caledonia: Secretariat of the Pacific Community.

RELINI, G., RELINI, M. \& MONTANARI, M. 2000. An offshore buoy as a small artificial island and a fish-aggregating device (FAD) in the Mediterranean. Hydrobiologia, 440, 65-80.

RELINI, M., ORSI, L. R. \& RELINI, G. 1994. An offshore buoy as a FAD in the Mediterranean. Bulletin of Marine Science, $55,1099-1105$.

SERVAIN, J., BUSALACCHI, A., MCPHADEN, M. J., MOURA, A. D., REVERDIN, G., VIANNA, M. \& ZEBIAK, S. 1998. A Pilot Research Moored Array in the Tropical Atlantic (PIRATA). Bulletin of the American Meteorology Society, 79, 2019-2031.

SILVA, G. B., CHAVES, D. B. \& FONTELES-FILHO, A. A. 2013. Aspectos econômicos da pesca de atuns e afins associada a uma boia oceânica no Atlântico Oeste Equatorial. Boletim do Instituto de Pesca de São Paulo, 39, 85-91.

SILVA, G. B., HAZIN, H. G., MOURATO, B. L., HAZIN, F. H. V. \& FONTELES-FILHO, A. A. 2016. Composição das capturas na pesca de atuns e afins em cardumes associados no Atlântico Oeste Equatorial. Boletim do Instituto de Pesca de São Paulo, 42, 866-877.

\section{ERRATA}

No artigo Fishing operations to catch tuna on aggregated schools at the vicinity of a data buoy in the Western

Equatorial Atlantic, com número de DOI: http://dx.doi.org/10.1590/s1679-87592018018206604, publicado no periódico Brazilian Journal of Oceanography, 66(4):335-338;2018.

Página 335

Onde se lia:

Guelson Batista da Silva ${ }^{*}$, Humberto Gomes Hazin ${ }^{1}$, Paulo Víctor Araújo do Nascimento²

Leia-se:

Guelson Batista da Silva ${ }^{1 *}$, Humberto Gomes Hazin ${ }^{1}$, Paulo Victor do Nascimento Araújo ${ }^{2}$ 